\title{
IMPLEMENTATION OF MULTICULTURAL EDUCATION TO TECHNICAL EDUCATION AT PRIMARY SCHOOL
}

\author{
Pavlína NAKLÁDALOVÁ
}

\begin{abstract}
The article deals with the implementation of multicultural education into the educational process of technical education at primary school. This article aims to highlight the common ground for both educational disciplines with an emphasis on broader humanizing aspects that are an essential part of technical education.
\end{abstract}

Key words: multicultural education, technical education, primary school, crosscutting theme

\section{IMPLEMENTACE MULTIKULTURNÍ VÝCHOVY DO TECHNICKÉ VÝCHOVY NA PRIMÁRNÍ ŠKOLE}

Resumé: Článek se zabývá problematikou implementace multikulturní výchovy do edukačního procesu technické výchovy na prvním stupni základní školy. Cílem článku je poukázat na společná východiska obou výchovných disciplín s důrazem na širší humanizační aspekty, které jsou nezbytnou součástí technické výchovy.

Klíčová slova: multikulturní výchova, technická výchova, primární škola, průřezové téma

\section{1 Úvod}

Současná společnost je ve velké miřre konfrontována $\mathrm{s}$ obrovskou kulturní pluralitou. Vzhledem k evropskému kolonialismu a následné migraci, je současná Evropa obrazem pestré škály kultur a lidí. V průběhu historie bylo možné zaznamenat mnoho střetů, jejichž vznik pramení mimo jiné $\mathrm{z}$ negativních postojů a předsudků vzniklých jako reakce na obranu vlastní kulturních hodnot. Zájmy a individuální politika již odnepaměti rozdělují lidi napříč národy, etnikem i náboženstvím.

Multikulturní výchova je často prezentována jako jeden $\mathrm{z}$ nástrojů umožňující pochopení komplikovanosti mezilidských vztahů, který má potenciál $\mathrm{k}$ rozvoji celospolečenského porozumění, tolerance a mírového řešení konfliktı̊. Mimo jiné lze tuto výchovu chápat jako způsob osobitého rozvoje individuality člověka (žáka), který má vést $\mathrm{k}$ rozvoji jedince, jehož chování a jednání by mělo mít pozitivní globální důsledky. Média i veřejné diskuse týkající se multikulturalismu a multikulturní výchovy mají tendence zjednodušovat fakta, aniž by se projevila snaha pátrat po pŕíčinách společenských dějů a událostí. Multikulturní výchova (a interkulturní vzdělávání ve světovém kontextu) chce žáky připravit ke skutečnému dialogu o historii, současnosti i budoucnosti a rozvíjet schopnost reflexe i sebereflexe. [1]
Již $\mathrm{v}$ minulosti se projevovaly snahy poskytnout vzdělání pro každého, jejíž cílem byla integrace jedince do společnosti. Dnešním problémem je však spíše otázka, jakým způsobem $\mathrm{s}$ odlišností zacházet, poznávat, hodnotit a propagovat za současného respektování individuálních specifik jedince. Koncept multikulturní výchovy je navržen tak, aby umožňoval lepší pochopení kultur, rozvíjel schopnost komunikace mezi lidmi např́íc kulturami, propagoval flexibilnější postoj ke kulturní odlišnosti ve společnosti a rozvíjel schopnost participace v sociální interakci. [16]

\section{Multikulturní výchova a interkulturní vzdělávání}

Pojmová diverzita se v českém prostředí často vyskytuje i v odborných publikacích, což způsobuje nejasnosti $\mathrm{v}$ interpretaci obsahu pojmů. Podobně jako je tomu ve světě, nejčastěji je možné setkat se s pojmy multikulturní (Průcha, Hladík, Gulová, Štěpařová aj.) a interkulturní (Šišková, Buryánek, Moree, Morvayová, Morgensternová aj.).

Termín multikulturní výchova byl převzat $\mathrm{z}$ anglického „multicultural education “ a je závazně stanoven jako průřezové téma Rámcového vzdělávacího programu pro základní vzdělávání (dále jen RVP ZV). Multikulturní výchova $\mathrm{v}$ základním vzdělávání umožňuje žákům ,seznamovat se s rozmanitostí různých 
kultur, jejich tradicemi a hodnotami. Na pozadi této rozmanitosti si pak žáci mohou lépe uvédomovat $i$ svoji vlastni kulturni identitu, tradice a hodnoty “. ${ }^{[4]}$ Postupným vývojem poznání a společnosti se však mění i př́stup $\mathrm{k}$ této disciplíně. Současné pojetí klade důraz především na individualitu a originální životní zkušenost vzdělávaných. S touto koncepcí koresponduje termín interkulturni vzdělávání, (interkulturni učení ${ }^{[14]}$ ). Přestože pojem interkulturní vzdělávání mnohem lépe vystihuje trendy a požadavky moderní doby, oficiálním pojmenováním, stanoveným kurikulárními dokumenty, zůstává termín multikulturní výchova.

Cíle interkulturního vzdělávání vyplývají $\mathrm{z}$ cílů stanovených $\mathrm{v}$ Národním programu rozvoje vzdèláváni v České republice. [3] Jedná se především o tyto cíle:

- rozvoj lidské individuality,

- zprostředkování historicky vzniklé kultury společnosti,

- posilování soudržnosti společnosti výchovou $\mathrm{k}$ lidským právưm a multikulturalitě,

- podpora demokracie a občanské společnosti, výchova k partnerství a solidaritě v evropské i globalizující se společnosti.

Cílovou skupinou multikulturní výchovy ve škole jsou především žáci. Konkrétně se jedná jak o žáky z majoritní společnosti, tak žáky pocházející $\mathrm{z}$ odlišného kulturního prostředí. Současně (přestože spíše zprostředkovaně) působí škola a učitel také na rodiny žáků. Uživání a prezentace získaných vědomostí, dovedností a postojů žáky může mít vliv na atmosféru v rodině i názory rodinných prŕslušníků. $Z$ pohledu soužití se jeví jako nejvýznamnější působení na žáky dominantní kultury, nebot' ti určují výchozí standardy a hodnoty. Právě žáci z majoritní populace jsou vystaveni snahám o změnu chápání vlastních kulturních norem jako všeobecně platných, neměnných či dokonce cennějších. Objevuje se výrazné úsilí o akceptování menšinových kultur a výchova ke spolupráci s nimi.

U zástupců minoritní kultury je nezbytný rozvoj tolerance jak vůči ostatním minoritám, tak vůči představitelům převažující kultury. Multikulturní výchova by měla všechny členy společnosti připravit na vzájemné soužití a zvyšovat úroveň a kvalitu interkulturní komunikace.
Pokud mají být naplněny všechny požadavky společnosti, je nezbytné zaměřit se především na učitele a budoucí učitele - studenty pedagogických fakult. Právě učitel je rozhodující faktor ovlivňující myšlení a prístup žákủ $\mathrm{k}$ mezilidskému soužití. Potřebné vlastností a dovednosti pedagogů je možné získávat a rozvíjet formou kurzů či studijních disciplín zaměřených na interkulturní vzdělávání. [10]

\section{Multikulturní výchova v kurikulárních dokumentech}

Interkulturní vzdělávání je v českých podmínkách relativně novým pedagogickým fenoménem. Zájem o tuto problematiku v průběhu let stále roste a multikulturní výchova začala být vnímána jako nástroj zlepšení vztahu mezi majoritní skupinou obyvatel a minoritami. [13] Přestože je v současné době Česká republika kulturně pluralitním státem, ze sociologických výzkumných šetření vyplývá, že značná část obyvatel stále vnímá soudobou společnost jako monokulturní. [18] Česká škola odpovídá na události ve společnosti reformou kurikulárních dokumentů, která má primárně sloužit $\mathrm{k}$ aktualizaci a zkvalitnění systému vzdělávání.

Základním dokumentem a zároveň prostředkem sloužícím $\mathrm{k}$ dosažení požadovaných změn je RVP ZV. Koncepce a pojetí RVP ZV navazuje na Rámcový vzdělávací program pro předškolní vzdělávání (RVP PV) a je východiskem

pro rámcový vzdělávací program pro střední vzdělávání (RVP GV, RVP SOV). Rámcový vzdělávací program pro základní vzdělávání vychází z nové strategie vzdělávání, která je založena na klíčových kompetencích jednotlivce, jejich provázanost se vzdělávacím obsahem a uplatnění získaných vědomostí a dovedností $\mathrm{v}$ praktickém životě, podporující koncepci celoživotního učení. Stěžejní je také snaha o podporu pedagogické autonomie škol a profesní odpovědnosti učitelů za výsledky vzdělávání. Cíle základního vzdělávání jsou v dokumentu definovány takto: „Základni vzděláváni má žákům pomoci utváret a postupně rozvíjet klićcové kompetence a poskytnout spolehlivý základ všeobecného vzdèláni orientovaného zejména na situace blizké životu a na praktické jednáni. " [6] Závazné rámce pro základní vzdělávání jsou do praxe implementovány prostřednictvím školních vzdělávacích programů (dále jen ŠVP), podle kterých se uskutečňuje vzdělávání na jednotlivých školách. 
Principy a zásady interkulturního vzdělávání jsou stanoveny RVP ZV formou průřezového tématu Multikulturní výchova. Prvky multikulturní výchovy by se měly objevovat $\mathrm{v}$ různých vzdělávacích oblastech a být součástí vyučovacích prredmětů. Rámcový vzdělávací program pro základní vzdělávání však umožňuje i vznik samostatného předmětu. Tato varianta implementace multikulturní výchovy do edukačního procesu je některými odborníky odmítána pro obavu nad zvýšenou sumou učiva a znalostí, které si musí žáci osvojit. [24]

Př́nos průřezového tématu Multikulturní výchova k rozvoji žáka je v RVP ZV definován v oblasti vědomostí, dovedností, schopností, postojů a hodnot. Současně jsou stanoveny dílčí tematické okruhy, jejichž výběr a realizace vychází z aktuální situace ve škole i společnosti. Vliv na volbu témat by měli mít jak učitelé, tak žáci (poprrípadě jejich rodiče). Oficiálně bylo stanoveno pět výchozích tematických okruhů, mezi které patří Kulturni diference, Lidské vztahy, Etnický pưvod, Multikulturalita a Princip sociálního smíru a solidarity.

Multikulturní př́stup je aplikován ve vzdělávacích oblastech Jazyk a jazyková komunikace, Člověk a společnost, Informačni a komunikačni technologie, Uměni a kultura, Člověk a zdraví, Človék a príroda. Vazba na tyto oblasti je dána tématy zabývající se vzájemným vztahem mezi prŕslušníky národů, etnických a sociokulturních skupin. Problém multikulturalismu ve školních podmínkách spočívá $v$ tom, že vzdělávací instituce často nesplňují požadavky masivního nárůstu populace žáků-cizinců a jejich rodin. Školy a vzdělávací instituce navíc podléhají kritice především proto, že skupiny obyvatel, které byly dříve „tradičně“ vyloučeny, jsou nyní součástí běžných škol a ty na to nejsou schopny efektivně reagovat. Interkulturní vzdělávání je hlavním prostředkem v boji o otázky týkající se národní identity, uchování historické paměti, účelem vzdělávání a smyslu demokracie. [11]

Obsah multikulturní výchovy a interkulturního vzdělávání vychází ze sociologického, psychologického a kulturologického základu. Tematicky se věnuje problematice člověka a jeho prostředí, lidské identitě, interpersonálním vztahům, globálním problémům lidstva aj. [23]

Současná koncepce Multikulturní výchovy tak, jak jej stanovuje RVP ZV, je vystavena četným kritikám odborníků (Moree, Morvayová, Janebová, Nikolai, Hajská aj.) Vznik negativních hodnocení a soudů je způsoben absencí reakcí českého školství na nové vývojové tendence $\mathrm{v}$ interkulturním vzdělávání. Neustálý rozvoj vzdělávacích trendů dává za vznik novým konceptům a modifikacím obsahu Multikulturní výchovy. Jednu z inovací multikulturní výchovy př̀dstavuje publikace Doporučené očekávané výstupy: Metodická podpora pro výuku prưrezových témat $v$ základnich školách [26], která specifikuje očekávané výstupy pro jednotlivé ročníky základní školy.

\section{Technická výchova na primární škole}

Primární škola konceptuálně navazuje a prohlubuje znalosti, dovednosti a postoje získané v průběhu předškolního vzdělávání přičemž klade důraz na celkový rozvoj klíčových kompetencí. Interdisciplinární zaměření primárního vzdělávání i technické výchovy umožňuje efektivně propojovat znalosti žáků s praktickými dovednostmi a jejich uplatněním $v$ běžném životě. Hlavním cílem technické výchovy je všeobecný rozvoj člověka, který zná své vlastnosti a schopnosti, systematicky pracuje na jejich rozvoji a dokáže je ve svém životě prakticky uplatnit. [20]

Technická výchova na primární škole je deklarována Rámcovým vzdělávacím programem pro základní vzdělávání především ve vzdělávací oblasti Člověk a svět práce. Tato oblast postihuje značné spektrum činností a technologií, které mají vést $\mathrm{k}$ získání základních dovedností $\mathrm{v}$ různých oborech lidské činnosti. [4] Současný koncept technického vzdělávání je zaměřen na poznatky zoblasti techniky a jejich aplikaci prostřednictvím řešení úloh, které vedou k uvědomění si dalších aspektů techniky. Mezi základní aspekty ovlivňující techniku a technickou výchovu je možné řadit např. humanitní využívání techniky, kam spadá např. problematika estetiky, ekologie, ekonomie, ergonomie a další. [8]

Mimo uvedené je třeba brát $\mathrm{v}$ potaz také multikulturní aspekty technické výchovy. Jestliže budeme chápat kulturu neboli civilizaci v nejširším etnografickém významu jako „komplexni celek, který zahrnuje znalosti, víru, uměni, mravy, právo, obyčeje a všechny dalši schopnosti a zvyky osvojené člověkem jako členem společnosti" [25], pak do tohoto konceptu musíme zahrnout i úroveň technického pokroku, způsoby uplatňování techniky, úroveň kompetencí v technické výchově na jednotlivých stupních škol aj. 
Cílem technické výchovy není pouhé předávání znalostí a osvojování dovedností, ale především se jedná o pochopení vzájemných souvztažností, rozvoj schopností řešit problémy v celé jejich širri, kriticky posuzovat a přemýšlet, spolupracovat.

Pojetí technického vzdělávání na primární škole by mělo respektovat dopad techniky na př́rodu a lidské společenství a současně odpovídat nejnovějším vzdělávacím trendům současnosti. Strategie technické výchovy 21. století by měla zahrnovat vedle inovace vzdělávacího obsahu také zkvalitnění interpersonálních vztahů (rozvoj spolupráce, komunikace, tolerance a respektu), vytváření didaktických situací a podmínek podporujících aktivní učení žáka (vycházejících z každodenních situací, se kterými se žáci mohou setkat). K hledání optimální podoby výuky je třeba reflektovat potřeby a možnosti rozvoje individua i (multikulturní) společnosti. [9]

Multikulturní výchova se v technické výchově nemusí objevovat pouze jako téma udávající podobu a výsledky praktických činností. Jako prưřezové téma by mělo ovlivnnovat a formovat charakter technicky zaměřených činností, uvádět je do kulturně-sociálněhistorických souvislostí a napomáhat tak dosahování cílů vytyčených pro technickou výchovu na primární škole. Vzájemné prolínání a ovlivňování rovněž vyplývá ze společných východisek obou výchovných předmětů.

\section{Společná východiska multikulturní a technické výchovy}

Multikulturní výchova vychází z ideových východisek tradičního pedagogického myšlení, ze kterých vybírá metody, cíle i témata a dále je modifikuje $\mathrm{v}$ duchu moderní pedagogiky. Výchozí myšlenky lze popsat prostřednictvím několika pohledů na jeden celek. Buryánek [1] uvádí pedagogický konstruktivismus, kritické myšlení, interaktivní výuku a kooperativní výuku. V souladu s aktuálními tendencemi prolínání multikulturní výchovy s osobnostně sociální výchovou dále doplňujeme o reflexi a sebereflexi jedince. [13]

Tyto aspekty odkazují na tematicky propojené oblasti, ze kterých jsou odvozeny konkrétní didaktické nástroje uplatňované $\mathrm{v}$ interkulturním vzdělávání. Mimo uvedené pilíře shrnující pedagogické a metodické principy je výuka ovlivněna také dalšími faktory, jako jsou osobnost pedagoga, atmosféra školního a trrídního kolektivu, věk žáků i jejich učební (pracovní) návyky.

\subsection{Pedagogický konstruktivismus}

Hlavním pilířem, představující filosofické, pedagogické a psychologické východisko multikulturní i technické výchovy je pedagogický konstruktivismus. Jedná se o rozsáhlý proud pojednávající o chování a sociálních vědách vyzdvihující aktivitu žáka, jeho vnitřní předpoklady a interakci s prostředím a společností. [19] Tento směr vychází z předpokladu, že člověk a společnost prochází procesem neustálé změny a poznání získáváme na základě vlastní zkušenosti. Smyslem vzdělávání pak není předávání hotových informací prezentovaných jako jediná „pravda“ tak, jak je tomu v prípadě transmisivní pedagogiky. Konstruktivistické didaktiky pracují s pojmem prekoncept, který je vnímán jako spontánní koncept, který si žák vytvořil na základě interakce s prostředím a který je třeba dále přetvářet. [21]

Dílčím úkolem multikulturní a současně i technické výchovy je vybavit žáka schopností orientace a efektivního využití množství poznatků, které přináší moderní doba, kde se poznatky liší v závislosti na obsahu výchovné disciplíny. Informace, které žák získává, bud'to zapadají do struktury prekonceptů nebo jsou s ní v rozporu a vyvolají určitou změnu. Pedagogický konstruktivismus je zaměřen na proces získávání vědomostí a prací pedagoga je usnadnit zapojení nových poznatků do již existujících mentálních struktur. Učení je chápáno jako sociální fenomén - spontánní nepřetržitá aktivita založená na řešení přirozených situací, nebot' znalosti získané během řešení problémů jsou trvalejší. V technické výchově se konstruktivismus projevuje např. volbou didaktických metod, při kterých je žákům umožňováno konstruovat vlastní poznání, a to při kreativních manipulativních činnostech.

\subsection{Kritické myšlení}

Ruku v ruce s pedagogickým konstruktivismem vstupuje do procesu kritické (pluralitní [12]) myšlení. Kritická analýza situace je aktivní proces založen na tvořivém myšlení a systematickém zpracování nových informací. Kriticky myslící jedinec si sám klade otázky: $C o$ si o tom myslím? Jak tato informace zapadá do toho, co již znám? Jak s novou informací naložit? Jaký vliv mají tyto informace, názory na mé miněni? [22] 
Kritické myšlení si klade za cíl osvojit schopnost objektivního vyhodnocení sociálních situací a mechanismů ve společnosti a tím umožnit jedinci pochopit svět v celé jeho komplexnosti. $\mathrm{V}$ oblasti interkulturního vzdělávání je kladen důraz na rozlišování př́ičin a následků společenských dějů a posuzování podmínek a okolností z více než jednoho úhlu pohledu, tedy $\mathrm{z}$ perspektivy nejen majoritní společnosti. Tohoto cíle lze dosáhnout prostř̌ednictvím dialogu, který je založen na zkoumání situace $\mathrm{z}$ více různých pohledů.

Zvládání situací spojených $\mathrm{s}$ účelným využitím techniky vyžaduje práci s informacemi podporovanou a ovlivňovanou kritickým myšlením a hodnocením, přijímáním rozhodnutí a způsobem jejich obhajoby. [17] Žák je veden $\mathrm{k}$ tomu, aby si utváŕel a vyjadřoval svůj názor a současně posuzoval průběh i výsledky činnosti (vlastní i ostatních). Přirozenou cestou se tak učí zdůvodňovat a obhajovat vlastní myšlenky, názory, vkus i celkový pohled na svět, který je automaticky konfrontován se stanovisky ostatních.

\subsection{Interakce}

Třetí pilír interkulturního vzdělávání upozorňuje na nezbytnost změny pedagogického př́stupu $\mathrm{k}$ žákům. Většina činností multikulturní výchovy je založena právě na vzájemném působení dvou nebo více činitelů. Interakci tedy lze definovat jako vzájemné ovlivňování jedincư, skupin a prostředi, které vyvolává určitou zménu. ${ }^{1}$ Inovovaný vztah učitele a žáka je založen na partnerství, spolupráci a vzájemném respektu. Interaktivní výuka jako jeden z hlavních didaktických principů konstruktivismu vyžaduje po žákovi aktivní účast při naplňování edukačních cílů.

Efektivní využití interaktivní výuky by mělo především vést $\mathrm{k}$ rozvoji tvůrčí atmosféry ve třídě. Na základě zpětné pozitivní vazby má podněcovat $\mathrm{k}$ vyjadřování vlastních myšlenek a názorů a vést $\mathrm{k}$ zodpovědnosti za společný cíl.

V technické výchově se tento způsob vytváření znalostí, dovedností a postojů může projevit napřr. v podobě volné tvorby žáků, kdy nejsou omezování užitím předem určených materiálů a pomůcek, ale je jim nabídnuta baterie prostředků, které mohou libovolně kombinovat a užívat dle vlastní fantazie. Žák se přirozeně stává zdrojem nápadů, myšlenek a způsobů řešení,

\footnotetext{
${ }^{1}$ HARTL, Pavel a Helena HARTLOVÁ. Psychologický slovnik. Praha: Portál, 2009. ISBN 978-80-7367-569-1.
}

přičemž role učitele se mění spíše na rádce a průvodce.

\subsection{Kooperace}

Další východisko doplňující pohled na interaktivní výuku směřuje $\mathrm{k}$ socializačnímu cíli výuky. Jestliže třetí piliřr vyžaduje při výuce maximální komunikaci, pak čtvrtý určuje její charakter. Kooperativní učení vychází z myšlenky spolupráce, prostřednictvím které je možné snadněji dosáhnout stanoveného cíle. Princip kooperace je založen na vzájemné pozitivní závislosti a podpoře činnosti jak jedince, tak celé skupiny. Role učitele je v tomto procesu modifikována specifickými rysy tohoto typu učení. Pedagog působí ve funkci manažera a konzultanta, který stanovuje edukační cíle, určuje velikost i složení skupin a rozhoduje o délce trvání činnosti skupiny.[6]

Kooperace jak mezi učitelem a žákem, tak mezi žáky navzájem je nezbytná především proto, že vytváríi návyk prrijímat cíle stanovené společností. Při spolupráci je do činnosti zapojen každý bez ohledu na jeho hodnocení či kategorizaci. Zároveň je pro efektivní spolupráci nutné, aby na sebe aktéŕi brali ohledy a byli vůči sobě navzájem tolerantní. Schopnost kooperace se má pro žáky stát určitou etickou normou, podle které se ř́ídí uspořádání vztahů $\mathrm{v}$ kulturně pluralitní společnosti. Spolupráce je zde vnímána jako protiklad k soupeření, které vede ke škálování a kategorizaci žáků. Kooperace prostřednictvím skupinové práce je v interkulturním vzdělávání prezentována jako nejvhodnější organizační formou.

V technické výchově je kooperace specifickou činností zejména pro charakter výsledného cíle. Hmatatelný výsledek je pro žáky mladšího školního věku pochopitelnější, nebot' si dokáží uvědomit potřebu aktivní participace na dosažení společného cíle.

\subsection{Sebereflexe}

Sebereflexe se stala fenoménem moderní doby a také ukazatelem posunu pedagogiky do osobnostní úrovně. Významnou součástí sebereflexe je schopnost ohlédnout se zpět, analyzovat své chování i jednání a objevit prvky, které nás pozitivně ovlivní a umožní vlastní růst. Mluvíme tedy o určitém sociálním a intelektuálním vědomí, které nás usměrňuje a řídí. V reflektivním myšlení jsou patrné tři základní elementy. Jedná se o složku kognitivní, soustředěnou na znalosti a rozhodování, dále je to kritická reflexe zahrnující zkušenost, cíle a 
hodnoty jedince. A posledním prvkem je vlastní interpretace (edukační) reality.

Proces reflexe a sebereflexe však slouží především k hledání a odkrývání zdrojů chování žáků, zamyšlení se nad př́činami jednání a odkrývání takových míst osobnosti, která jsou dosud nepoznaná.[15] Pokud učitel nevede žáky k reflexi, (nejen při manipulativních technických činnostech) tedy není reflektivním učitelem, ztrácí současně schopnost přizpůsobovat sebe i své jednání proměnlivým školním podmínkám i chování žáků.

\section{Závěr}

Článek se zabývá implementací průřezového tématu Multikulturní výchova do technické výchovy na prvním stupni základních škol. Vzhledem $\mathrm{k}$ charakteru technické výchovy na primární škole, který je ovlivněn jednak interdisciplinaritou a jednak specifičností technických činností je možné multikulturní výchovu do výuky aplikovat mnoha různými způsoby. Praktický charakter aktivit v technické výchově umožňuje využít témata multikulturní výchovy hlouběji, než pouze jako propojující prvek jednotlivých činností. Přri analýze teoretických východisek obou výchovných disciplín zjistíme, že je možné (a žádané) implementovat prưř̀zové téma $\mathrm{s}$ důrazem na společné edukační cíle.

V tomto procesu je rozhodující role učitele, která by měla v souladu $\mathrm{s}$ aktuálními trendy spočívat především ve snaze o rozvoj osobnostních kvalit jedince, a to prostřednictvím činností žákovi blízkých, které zohledňují širší humanizační aspekty technické výchovy. Prostřednictvím tvưrčích aktivit je možné rozvíjet kreativitu, dovednost řešit problémy, komunikaci a kooperaci, hodnocení i sebehodnocení, v závislosti na tom je možné pozitivně ovlivnit i žákovo sebepojetí a identitu.

V souvislosti s výše uvedeným se nabízí otázky k podrobnějšímu zkoumání: Jakým zpưsobem učitelé implementuji průřezová témata do výuky? Které aspekty techniky učitelé považuji za důležité pro výuku na primární škole? Jaké jsou postoje a názory učiteli $k$ multikulturní výchově na primární škole? A mnohé další.

\section{Literatura}

[1] BURYÁNEK, J. Interkulturni vzděláváni I. [online]. Praha: Člověk v tísni, 2002. Dostupné z: http://www.varianty.cz/cdrom/podkapitoly/IKV1_ komplet.pdf.
[2] COUNCIL OF EUROPE. T-Kit: Intercultural learning [online]. 4. vyd. Council of Europe, 2000. Dostupné z: http://youth-partnershipeu.coe.int/youth-

partnership/documents/Publications/T_kits/4/tkit 4.pdf

[3] ČESKO. Národní program rozvoje vzdělávání: Bílá kniha. Praha: Ministerstvo školství, mládeže a tělovýchovy, 2001. 98 s. Dostupné z: http://aplikace.msmt.cz/pdf/bilakniha.pdf. ISBN 80-211-0372-8.

[4] ČESKO. Rámcový vzdělávací program pro základni vzděláváni: (se změnami provedenými $k$ 1.9.2007). Praha: Výzkumný ústav Praha, 2007. 126 s. Dostupné z: http://www.vuppraha.cz/wpcontent/uploads/2009/12/RVPZV_2007-071.pdf.

[5] HARTL, P., HARTLOVÁ, H. Psychologický slovnik. Praha: Portál, 2009. ISBN 978-80-7367569-1.

[6] KASÍKOVÁ, H. Kooperativní učení. In [7] VALIŠOVÁ, A., KASÍKOVÁ, H. (eds.) Pedagogika pro učitele. Praha: Grada, 2007. ISBN 978-80-247-1734-0.

[8] KOŽUCHOVÁ, M. Elementárna technická výchova detí predškolského a mladšieho školského veku. In. Předškolni a primární pedagogika. Vyd. 1. Editor Zuzana Kolláriková, Branislav Pupala. Praha: Portál, 2001, 455 s. ISBN 80-717-8585-7.

[9] KROPÁČC, J., CHRÁSKA, M.. Výchova $v$ obecně technických predmětech. 1. vyd. Olomouc: Univerzita Palackého v Olomouci, 2004, ISBN 80-244-0897-X.

[10] MISTRÍK, E. Multikultúrna výchova ve škole: Ako reagovat na kultúrnu roznorodost' [online]. Bratislava: Nadácia otvorenej spoločnosti, 2008. ISBN 987-80-969271-4-2. Dostupné $\mathrm{z}:$ http://www.erichmistrik.sk/knihy/osnovy/osnovy. htmlhttp://www.erichmistrik.sk/knihy/osnovy/os novy.html.

[11] MODOOD, T. Multiculturalism: a civic idea. Cambridge: Polity Press, 2007. ISBN 97807456-3288-9.

[12] MOREE, D. Czechkid: Multikulturní výchova. Czechkid [online]. Dostupné z: http://www.czechkid.cz/si1390.html

[13] MOREE, D. Než začneme s multikulturní výchovou: od skupinových konceptů $\mathrm{k}$ osobnostnímu př́stupu [online]. Praha: Člověk v tísni o.p.s., 2008. Dostupné z: http://www.varianty.cz/download/pdf/pdfs 70.pd f. 
[14] Národní institut dětí a mládeže MŠMT. Interkulturni učení: T-Kit [online]. Praha: Galio Crossmedia, 2007 [cit. 2012-10-31]. Dostupné z: http://youth-partnership-eu.coe.int/youthpartnership/documents/Publications/T_kits/4/Cze ch/T-Kit_4_cs.pdf. ISBN 978-80-86784-55-7.

[15] NEZVALOVÁ, D. 1. vyd. Olomouc: Univerzita Palackého v Olomouci, 2000, 72 s. ISBN 80-244-0208-4.

[16] OUELETT, F. and E. G. COHEN. Les défis du pluralisme en éducation: essais sur la formation interculturelle. Laval: Presses Université Laval, 2002. ISBN 2-7637-7857-87.

[17] PLISCKE, J., KROPÁČ, J. Kritické myšlení a možnosti jeho rozvíjení $\mathrm{v}$ technických předmětech na ZŠ. In Trendy ve vzděláváni 2010. Informačni technologie a technické vzdělávání. Díl I. Olomouc: ALTYN, 2010, s. 222-225. ISBN 978-80-87224-09-0.

[18] PRUDKÝ, L. Přináležitost k národu, vztahy k jiným národnostem a cizincuim $v$ České republice. Praha: FHS UK, 2004. ISBN 9788072-04359-0.

[19] PRŮCHA, J., WALTEROVÁ, E., MAREŠ, J.. Pedagogický slovník. 6., rozš. a aktualiz. vyd. Praha: Portál, 2009, ISBN 978-807-3676-476

[20] ROUČOVÁ, E. Didaktika technických praci na primárni škole. Distanční text. České Budějovice: PdF JČU, 2003.

[21] SKALKOVÁ, J. Obecná didaktika. Praha: Grada, 2007. 2. akt. a rozš. vyd. ISBN 978-80247-1821-7.

[22] STEEL, J. L., (ed.). Kritické myšlení napřič osnovami: Čtením a psaním ke kritickému myšleni: Př́ručka I. Praha: Kritické myšlení, 1997.
[23] ŠIŠKOVÁ, Tat'ána. (ed.) Výchova ktoleranci a proti rasismu: Multikulturní výchova v praxi. Praha: Portál, 2008. ISBN 97880-7367-182-2.

[24] TANCOŠ, Ján. Multikultúrná výchova: súčasný stav a jej úloha $\mathrm{v}$ integračním procese společnosti. In. GULOVÁ, Lenka a Eliška ŠTĚPAŘOVÁ (eds.). Multikulturní výchova $\mathrm{v}$ teorii a praxi. Brno: Katedra sociální pedagogiky Pedagogické fakulty MU, 2004, 2937. ISBN 80-8663-324-4.

[25] TYLOR, Edward Burnett. Primitivní kultura. 1871. In. SOUKUP, Martin. Kultura: Biologická perspektiva. Červený Kostelec: Pavel Mervart, 2011. ISBN 978-80-87378-96-0.

[26] Výzkumný ústav pedagogický v Praze. Doporučené očekávané výstupy: Metodická podpora pro výuku průrezových témat $v$ základních školách [online]. Praha: Výzkumný ústav pedagogický v Praze, 2011 [cit. 2012-1101]. s. 43-52. Dostupné z: http://digifolio.rvp.cz/artefact/file/download.php? file $=29411 \&$ view $=4021$. ISBN 978-80-8700076-2.

Mgr. Pavlína Nakládalová

Katedra primárního vzdělávání

Pedagogická fakulta UP

Žižkovo nám. č. 5

77140 Olomouc, ČR

Tel: +420 585635108

E-mail: pavlina.nakladalova@upol.cz

Www pracoviště: www.kpv.upol.cz 